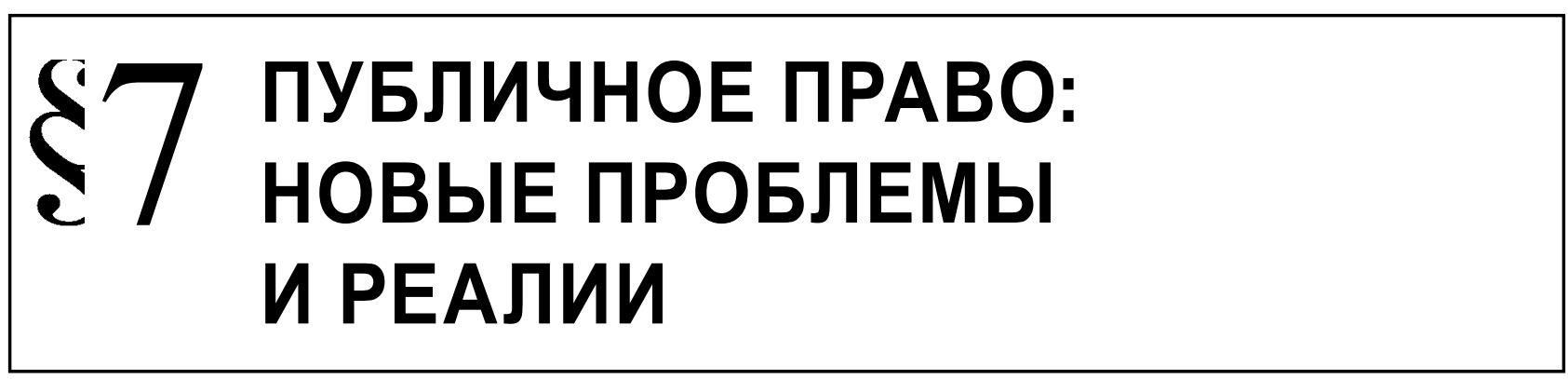

Акопджанова М.О.

\title{
ВОПЛОЩЕНИЕ ПРИНЦИПА ВЕРХОВЕНСТВА ПРАВА В ЗАКОНОДАТЕЛЬСТВЕ И ПРАВОПРИМЕНИТЕЛЬНОЙ ДЕЯТЕЛЬНОСТИ
}

Аннотация: Действующая Конституция Российской Федерации 1993 года закрепила международно-правовой принцип верховенства права в положениях, составляющих основы конституционного строя страны. Имея статус международного и конституционного, данный принцип лёг в основу федерального, регионального и местного законодательства. С челью дальнейшего воплощения принципа верховенства права ряд норм действующего российского законодательства нуждаются в уточнении, связанном, в первую очередь, с сужением категории «оценочности» в законе. В рамках настоящей статьи рассматриваются возможные варианты уточнения диспозиций норм закона, направленные на обеспечение единообразия правоприменительной практики. Методологической основой исследования явилась совокупность общенаучных и специальных методов постижения объективной социально-правовой действительности в исследуемой области: методы анализа, синтеза, систематизации и обобщения, формально-логический, статистический и социологический методы. В статье исследуются и анализируются важнейшие аспекты и признаки международного принципа верховенства права и особенности его воплощения в российском законодательстве. $B$ процессе исследования, исходя из анализа правоприменительной практики были выявлены существующие проблемы функционирования данного принципа и предложены возможные способы их устранения.

Ключевые слова: Право, верховенство, закон, правоприменительная деятельность, принцип, международные акты, нормы российского права, диспозиции уголовно-правовых норм, совершенствование, единообразие судебной практики.

$\Pi$ ринцип верховенства права является одним из важнейших принципов законодательной павоприменительной деятельности, нашедших отражение в международном и российском праве.

К числу международных актов, закрепляющих принцип верховенства права в качестве основополагающего, можно отнести Европейскую конвенцию о правах человека 1950 г., Заключительный документ Копенгагенской встречи 1990 г. ОБСЕ, Амстердамский договор Европейского союза 1997 г., Декларация тысячелетия ООН 2000 г., Итоговый документ Всемирного саммита $\mathrm{OOH}$ 2005 г., ежегодные с 2006 года резолюции Генеральной Ассамблеи $\mathrm{OOH}$ «Верховенство права на национальном и международном уровнях», Доклад Генерального секретаря 0ОН на 66-й сессии
Генеральной Ассамблеи ООН «Распространение правосудия: программа действий по усилению верховенства права на национальном и международном уровнях» 2011 г.).

В Докладе Генерального секретаря ОOH принцип верховенства права трактуется как присутствие правосудия на каждом уровне развития общества; гарантия защиты всего спектра прав человека и возможности по восстановлению прав; способность властей создавать и реализовывать ясные, публичные и справедливые законы; беспристрастная и подотчётная публичная служба; обеспечение устойчивого человеческого развития ${ }^{1}$.

\footnotetext{
Report of the Secretary-General "Delivering justice: programme of action to strengthen the rule of law at the national
} and international levels". UN Doc.A/66/749. 
В качестве признаков верховенства права в Докладе Генерального секретаря ООН называются: примат международного права; господство права; равенство перед законом; справедливость в правоприменении законодательной практики; разделение властей; правовая определённость; процессуальная и правовая прозрачность; суверенное равенство государств; добросовестное выполнение обязательств по Уставу ООН; повышение роли Международного суда в современной международной системе ${ }^{2}$.

В соответствии со ст. 15 Конституции Российской Федерации общепризнанные принципы и нормы международного права, а также международные договоры Российской Федерации являются частью правовой системы России. Международный принцип верховенства права нашёл отражение во внутреннем законодательстве России, трансформировавшись в конституционный принцип.

Согласно Концепции внешней политики Российской Федерации от 12 февраля 2013 года, верховенство права является одним из приоритетов России в решении глобальных проблем, подчёркивает соблюдение всеми участниками международных обязательств, выполнение общепризнанных норм международного права, обеспечение универсальности международных договоров $\mathrm{OOH}$ и их единообразное толкование и применение, укрепление европейского и других региональных правовых пространств.

Международный и конституционный принцип верховенства права нашёл отражение в российском законодательстве, был воспринят всеми отраслями российского права. В то же время анализ правоприменительной практики свидетельствует о необходимости дальнейшего совершенствования механизма претворения принципа верховенства права в действующее законодательство.

В частности, в подобном совершенствовании нуждается трактовка ряда норм уголовного закона.

Например, действующее уголовное законодательство России предусматривает ответственность за злостное неисполнение представителем власти, государственным служащим, служащим органа местного самоуправления, а также служащим государственного или муниципального учреждения, коммерческой или иной организации вступивших

\footnotetext{
2 См.: Марочкин С.Ю. Верховенство права на внутригосударственном и международном уровнях: динамика развития и взаимодействия // Государство и право. - 2013. - № 10. C. 85-94.
}

в законную силу приговора суда, решения суда или иного судебного акта, а равно воспрепятствование их исполнению (ст. 315 УК РФ). В качестве мер ответственности за уголовно наказуемое неисполнение судебного акта ст. 315 УК РФ предусматривает следующие альтернативные виды наказания:

- штраф в размере до двухсот тысяч рублей или в размере заработной платы или иного дохода осужденного за период до восемнадцати месяцев;

- $\quad$ лишение права занимать определенные должности или заниматься определенной деятельностью на срок до пяти лет;

- обязательные работы на срок от ста восьмидесяти до двухсот сорока часов;

- $\quad$ арест на срок от трех до шести месяцев;

- $\quad$ лишение свободы на срок до двух лет.

Объектом данного преступления являются общественные отношения, возникающие в процессе осуществлениями судами правосудия по всем категориям дел применительно ко всем предусмотренным законом инстанциям. В качестве предмета преступления выступают приговор суда, решение суда или иной судебный акт.

По смыслу закона объективная сторона уголовно наказуемого неисполнения приговора суда, решения суда или иного судебного акта, а равно воспрепятствования их исполнению может характеризоваться как активными действиями, как и бездействием в форме злостного неосуществления надлежащих действий в отношении указанных в соответствующим судебном акте лиц в порядке, данным судебном актом или законом регламентированным.

Субъективная сторона преступления характеризуется виной в форме прямого умысла: виновный осознаёт общественную опасность своего преступного поведения и продолжает его осуществлять. Субъект преступления, предусмотренного ст. 315 УК РФ, - специальный: представитель власти, государственный служащий, служащий органа местного самоуправления, а также служащий государственного или муниципального учреждения, коммерческой или иной организации.

Как показывает анализ судебной, прокурорской и следственной практики, в процессе применения диспозиции данной нормы правоприменитель сталкивается с рядом трудностей, обусловленным оценочным характером содержащегося в ст. 315 УК РФ термина «злостное неисполнение приговора суда, решения суда или иного судебного акта». На практике отсутствует однозначная оценка понятия «злостный». 
В этой связи данная норма уголовного закона нуждается в уточнении. В законе необходимо определить, что понимается под злостным неисполнением приговора суда, решения суда или иного судебного акта. Именно закон, и только закон должен определять, являются ли те или иные деяния преступлением.

Как представляется, подобное уточнение возможно посредством введения примечания к ст. 315 УК РФ, содержащего дефиницию термина «злостное неисполнение приговора суда, решения суда или иного судебного акта», характеризующуюся указанием на уголовную противоправность вторичного нарушения административно-правового запрета в сфере правосудия (административная преюдиция). Действующий Кодекс Российской Федерации об административных правонарушениях (глава 17) (далее - КоАП РФ) содержит ряд статей, предусматривающих административную ответственность за совершение правонарушений в сфере правосудия. Например, согласно ст. 17.4 КоАП РФ, наказуемым в административном порядке признаётся оставление должностным лицом без рассмотрения частного определения суда или представления судьи либо непринятие мер по устранению указанных в определении или представлении нарушений закона.
В силу того, что состав преступления, предусмотренный ст. 315 УК РФ, является формальным (в качестве условия привлечения к уголовной ответственности по данной статье не требуется причинения какого-либо ущерба или наступления иных противоправных последствий; преступление признаётся оконченным с момента совершения перечисленных в диспозиции рассматриваемой уголовно-правовой нормы действий (бездействия)), соответственно его наличие должно обусловливаться повышенной степенью общественной опасности деяния, выражающейся, в числе прочего, интенсивностью совершения действий (бездействия), характеризующих административное правонарушение (количественный показатель общественной опасности).

Думается, внесение соответствующего уточнения диспозиции нормы уголовного закона могло бы способствовать существенного снижению категории «оценочности» данной нормы, пределов усмотрения правоприменителя, устранению коррупциогенных факторов, обеспечению единообразия правоприменительной деятельности, что, в свою очередь, повысило бы уровень эффективности функционирования принципа верховенства права и закона на практике.

\section{Библиография:}

1. Марочкин С.Ю. Верховенство права на внутригосударственном и международном уровнях: динамика развития и взаимодействия // Государство и право. - 2013.-№ 10. - С. 85-94.

2. Полищук Д.А. Критериальная база оценки эффективности правоохранительной деятельности // NB: Российское полицейское право.-2014.-1.-C. 1-8. URL: http://www.e-notabene.ru/pm/ article_9270.html

3. Л.В. Филатова Влияние общепризнанных принципов и норм международного права на развитие информационного законодательства в России // Журнал зарубежного законодательства и сравнительного правоведения.-2011.-6.-С. 79-86.

4. Каламкарян Р.А. Включенность Российской Федерации в деятельность Международного Суда ООН в деле обеспечения международной законности и правопорядка // NB: Международное право.-2013.2.-C. 85-118. URL: http://www.e-notabene.ru/wl/article_691.html

5. Агапов А.Б. Административное законодательство и публичные правоограничения // Административное и муниципальное право.-2011.-10.-С. 74-79.

6. Гуляихин В.Н. Диалектика естественного и позитивного права как источник общественно-правового прогресса // NB: Вопросы права и политики.-2013.-№3.-C. 221-238. URL: http://www.e-notabene.ru/lr/ article_559.html.

\section{References (transliterated):}

1. Marochkin S.Yu. Verkhovenstvo prava na vnutrigosudarstvennom i mezhdunarodnom urovnyakh: dinamika razvitiya i vzaimodeistviya // Gosudarstvo i pravo. - 2013.-№ 10. - S. 85-94.

2. Polishchuk D.A. Kriterial'naya baza otsenki effektivnosti pravookhranitel'noi deyatel'nosti // NB: Rossiiskoe politseiskoe pravo.-2014.-1.-C. 1-8. URL: http://www.e-notabene.ru/pm/article_9270.html 
3. L.V. Filatova Vliyanie obshchepriznannykh printsipov i norm mezhdunarodnogo prava na razvitie informatsionnogo zakonodatel'stva v Rossii // Zhurnal zarubezhnogo zakonodatel'stva i sravnitel'nogo pravovedeniya.-2011.-6.-C. 79-86.

4. Kalamkaryan R.A. Vklyuchennost' Rossiiskoi Federatsii v deyatel'nost' Mezhdunarodnogo Suda OON v dele obespecheniya mezhdunarodnoi zakonnosti i pravoporyadka // NB: Mezhdunarodnoe pravo.-2013.-2.-C. 85-118. URL: http://www.e-notabene.ru/wl/article_691.html

5. Agapov A.B. Administrativnoe zakonodatel'stvo i publichnye pravoogranicheniya // Administrativnoe i munitsipal'noe pravo.-2011.-10.-C. 74-79.

6. Gulyaikhin V.N. Dialektika estestvennogo i pozitivnogo prava kak istochnik obshchestvenno-pravovogo progressa // NB: Voprosy prava i politiki.-2013.-№3.-C. 221-238. URL: http://www.e-notabene.ru/lr/ article_559.html. 